\title{
Bag urine specimens still not appropriate in diagnosing urinary tract infections in infants
}

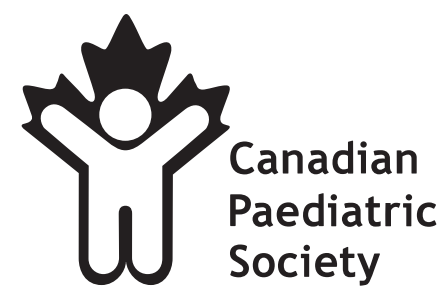

Daediatric urinary tract infections (UTI) are common, occurring in 1.7 and 3.1 per 1000 boys and girls, respectively $(1,2)$. Most UTIs are uncomplicated infections of the lower urinary tract and resolve with appropriate treatment. However, for reasons that are not yet fully understood, some patients, particularly those with vesicoureteral reflux, experience permanent renal scarring, hypertension and renal insufficiency (3). It has been estimated that about $7 \%(4)$ to $10 \%(5,6)$ of children with a febrile UTI without reflux will develop renal scarring, while the risk increases to $13 \%$ if there is low grade reflux and $53 \%$ if there is high grade reflux (4). About $20 \%$ of patients with renal scarring progress to develop hypertension and 5\% progress to end stage renal failure (4). Thus, accurate and timely diagnosis is paramount to preventing such sequelae.

Up to $6 \%$ of all infants presenting with fever to an emergency department will have a UTI (7-10). The clinical presentation of UTI in infants may be nonspecific, ranging from 'asymptomatic' bacteriuria with subtle clues such as enuresis or squatting to the very ill neonate with urosepsis presenting with lethargy and hypotension (2). Symptoms can also include vomiting, diarrhea, irritability, screaming, weight loss and prolonged jaundice. Current Canadian Paediatric Society guidelines recommend that for the evaluation of toxic appearing children less than three years old with fever (lower than $39.0^{\circ} \mathrm{C}$ rectal or $38.5^{\circ} \mathrm{C}$ oral) without focus, urinalysis and urine culture should be obtained (11). Accurate urine collection methods are key to obtaining a diagnosis of UTI in these young children (4). Obtaining urine samples from nontoilet trained children (ie, younger than three years of age) involves three main methods with varying contamination rates and invasiveness: suprapubic aspiration (SPA), uretheral catheterization and perineal bagging (bag urine) (Table 1) (4). Both uretheral catheterization and SPA are reliable methods for specimen collection but are invasive $(12,13)$. SPA involves using a needle and syringe setup to collect urine directly from the bladder through an aseptic area of the skin, providing the most microbiologically accurate sample for urine culture (14). In neonates, use of ultrasound guidance simplifies SPA and improves the diagnostic yield of obtaining a urine specimen from $60 \%$ to almost $97 \%(15,16)$. Urethral catheterization requires the insertion of a sterile number 5 feeding tube or the equivalent into a cleansed urethra. Careful insertion is required to prevent urethral trauma. This method has a specificity of $83 \%$ to $89 \%$ compared with
SPA in identification of UTIs; this improves to $99 \%$ if only cultures with greater than 1000 colony forming units/mL are considered $(7,17,18)$. Urethral catheterization has a success rate in obtaining a urine specimen that may be as low as $23 \%$ or as good as $90 \%$ depending on the physical condition of the infant and the expertise of the personnel involved (18-20). Bag urine collection involves taping a sterile plastic collection bag over the genitalia and waiting for the child to void into it. Although this method is noninvasive and is often the clinician's 'kindest' choice, it has the highest rate of contamination (up to $50 \%$ ), commonly with periurethral flora (20-25). In many hospitals and outpatient settings, bag urine collection is the initial method of choice among nurses and doctors because of its simplicity and noninvasiveness. As a result, there is often a reluctance to use other confirmatory sample collection methods.

UTI diagnosis should be as accurate and rapid as possible because there may be side effects (ie, anaphylaxis, rash, diarrhea, etc) of antimicrobial agents, possible unnecessary radiological investigations, frequent hospital visits for outpatient intravenous antibiotic therapy, and the possibility of admission to hospital (younger than three months of age). A detailed decision analysis was performed by the American Academy of Pediatrics in 1999 (4). In this analysis, culture of bag urine was considered to be $100 \%$ sensitive and $70 \%$ specific. Applying this to a theoretical cohort of 100,000 children, use of bag urine specimens for diagnosing UTI would cost $\$ 72.5$ million, lead to 33,500 imaging workups and would be associated with 42.4 cases of hypertension, 20.3 end stage renal disease cases and one death. In contrast, use of urethral catheterization or SPA would cost $\$ 25.3$ million, lead to 5000 imaging workups and be associated with similar numbers of hypertension,

\section{TABLE 1}

Advantages and disadvantages of the three methods for obtaining urine specimens from infants

\begin{tabular}{llll}
\hline & $\begin{array}{c}\text { Suprapubic } \\
\text { aspiration }\end{array}$ & $\begin{array}{c}\text { Urethral } \\
\text { catheterization }\end{array}$ & $\begin{array}{c}\text { Perineal bag } \\
\text { specimen }\end{array}$ \\
\hline Advantages & Most accurate & Very accurate & Simple, noninvasive \\
Disadvantages & $\begin{array}{l}\text { Invasive, technical } \\
\text { expertise needed, } \\
\text { variable yield }\end{array}$ & urethral trauma & $\begin{array}{c}\text { High contamination } \\
\text { rates, unnecessary } \\
\text { investigations and } \\
\text { high overall cost }\end{array}$ \\
\hline
\end{tabular}


end-stage renal disease and death. Due to the high contamination rates, and the less than favourable risk profile, the American Academy of Pediatrics concluded that bag urine specimens are not useful for diagnosing UTI and should always be followed up with another method in young children to confirm the diagnosis. However, urine obtained from a bag urine collection is useful for dipstick urinalysis and microscopic evaluation and a negative urine culture is highly specific for ruling out UTI (19-25). There are currently no new data to motivate any changes to this recommendation. The Canadian Paediatric Society's Infectious Diseases and Immunization Committee makes the following recommendations to clinicians:

- Any diagnosis of UTI that is made with a bag urine specimen in young infants requires confirmation with another method (SPA or urethral catheterization) before treatment and radiological investigation. In neonates, the use of ultrasound substantially improves the diagnostic yield of SPA;

- Urine obtained from a bag urine collection is useful for dipstick urinalysis and microscopic evaluation and a negative urine culture is highly specific for ruling out UTI;

- In a setting of acute sepsis or suspected sepsis where empirical antibiotics are to be instituted on an urgent basis, screening bag urine specimens are not recommended because follow-up confirmatory specimens would be affected by the instituted empirical antibiotics;

- All urine specimens should be transported to the processing laboratory for culture as quickly as possible after voiding; and

- There is an imminent need for training of staff in emergency departments and ambulatory clinics in appropriate methods of urine collection that minimize contamination (SPA and urethral catheterization).

\section{REFERENCES}

1. Winberg J, Andersen HJ, Bergstrom T, Jacobsson B, Larson H, Lincol NK. Epidemiology of symptomatic urinary tract infection in childhood. Acta Paediatr Scand Suppl 1974;252:1-20.

2. Zelikovic I, Adelman RD, Nancarrow PA. Urinary tract infections in children. An update. West J Med 1992;157:554-61.

3. Berg UB, Johansson SB. Age as a main determinant of renal functional damage in urinary tract infection. Arch Dis Child 1983;58:963-9.

4. Downs SM, for the American Academy of Pediatrics, Committee on Quality Improvement, Urinary Tract Subcommitte. Technical report:
Urinary tract infections in febrile infants and young children. Pediatrics 1999;103:e54.

5. Hoberman A, Charron M, Hickey RW, Baskin M, Kearney DH, Wald ER. Imaging studies after a first febrile urinary tract infection in young children. N Engl J Med 2003;348:195-202.

6. Hoberman A, Wald ER, Hickey RW, et al. Oral versus initial intravenous therapy for urinary tract infections in young febrile children. Pediatrics 1999;104(1 Pt 1):79-86.

7. Bonadio WA. Urine culturing technique in febrile infants. Pediatr Emerg Care 1987;3:75-8.

8. Hoberman A, Chao HP, Keller DM, Hickey R, Davis HW, Ellis D. Prevalence of urinary tract infection in febrile infants. J Pediatr 1993;123:17-23.

9. Roberts KB, Charney E, Sweren RJ, et al. Urinary tract infection in infants with unexplained fever: A collaborative study. J Pediatr 1983;103:864-7.

10. Bauchner H, Philipp B, Dashefsky B, Klein JO. Prevalence of bacteriuria in febrile children. Pediatr Infect Dis J 1987;6:239-42.

11. Canadian Paediatric Society, Infectious Diseases and Immunization Committee. Management of the febrile one- to 36-month-old child with no focus of infection. Paediatr Child Health 1996;1:41-5.

12. Redman JF, Bissada NK. Direct bladder catheterization in infant females and young girls: Description of an effective and painless procedure. Clin Pediatr 1976;15:1060-1.

13. Aronson AS, Gustafson B, Svenningsen NW. Combined suprapubic aspiration and clean-voided urine examination in infants and children. Acta Paediatr Scand 1973;62:396-400.

14. Hansson S, Brandstrom P, Jodal U, Larsson P. Low bacterial counts in infants with urinary tract infection. J Pediatr 1998;132:180-2.

15. Buys H, Pead L, Hallett R, Maskell R. Suprapubic aspiration under ultrasound guidance in children with fever of undiagnosed cause. BMJ 1994;308:690-2.

16. Kiernan SC, Pinckert TL, Keszler M. Ultrasound guidance of suprapubic bladder aspiration in neonates. J Pediatr 1993;123:789-91.

17. Kramer MS, Tange SM, Drummond KN, Mills EL. Urine testing in young febrile children: A risk-benefit analysis. J Pediatr 1994;125:6-13.

18. Pryles CV, Atkin MD, Morse TS, Welch KJ. Comparative bacteriologic study of urine obtained from children by percutaneous suprapubic aspiration of the bladder and by catheter. Pediatrics 1959;24:983-91.

19. Djojohadipringgo S, Abdul Hamid RH, Thahir S, Karim A, Darsono I. Bladder puncture in newborns - a bacteriological study. Paediatr Indones 1976;16:527-34.

20. Leong YY, Tan KW. Bladder aspiration for diagnosis of urinary tract infection in infants and young children. J Singapore Paediatr Soc 1976;18:43-7.

21. Schlager TA, Hendley JO, Dudley SM, Hayden GF, Lohr JA. Explanation for false-positive urine cultures obtained by bag technique. Arch Pediatr Adolesc Med 1995;149:170-3.

22. Schlager TA, Lohr JA. Urinary tract infection in outpatient febrile infants and children younger than 5 years of age. Pediatr Ann 1993;22:505-9.

23. Taylor CM, White RH. The feasibility of screening preschool children for urinary tract infection using dipslides. Int J Pediatr Nephrol 1983;4:113-4.

24. Sorensen K, Lose G, Nathan E. Urinary tract infections and diurnal incontinence in girls. Eur J Pediatr 1988;148:146-7.

25. Shannon FT, Sepp E, Rose GR. The diagnosis of bacteriuria by bladder puncture in infancy and childhood. Aust Paediatr J 1969;5:97-100.

CANADIAN PAEDIATRIC SOCIETY, INFECTIOUS DISEASES AND IMMUNIZATION COMMITTEE (2003-2004)

Members: Drs Upton Allen, The Hospital for Sick Children, Toronto, Ontario; H Dele Davies, Michigan State University, East Lansing, Michigan, USA; Simon Richard Dobson, BC's Children Hospital, Vancouver, British Columbia; Joanne Embree, The University of Manitoba, Winnipeg, Manitoba (Chair); Joanne Langley, IWK Health Centre, Halifax, Nova Scotia; Dorothy Moore, The Montreal Children's Hospital, Montreal, Quebec; Gary Pekeles, The Montreal Children's Hospital, Montreal, Quebec (Board Representative)

Consultants: Drs Gilles Delage, Héma-Québec, Saint-Laurent, Québec; Noni MacDonald, Dalhousie University, Halifax, Nova Scotia Liaisons: Drs Scott Halperin, IWK Health Centre, Halifax, Nova Scotia (IMPACT); Susan King, The Hospital for Sick Children, Toronto, Ontario (Canadian Paediatrics AIDS Research Group); Monica Naus, BC Centre for Disease Control, Vancouver, British Columbia; Larry Pickering, Centre for Disease Control and Prevention, Atlanta, Georgia, USA (American Academy of Pediatrics, Committee on Infectious Diseases)

Principal author: Dr H Dele Davies, Michigan State University, East Lansing, Michigan, USA

The recommendations in this statement do not indicate an exclusive course of treatment or procedure to be followed. Variations, taking into account individual circumstances, may be appropriate. This article also appears in Paediatr Child Health 2004;9(6):377-378 


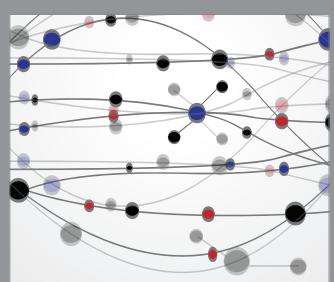

The Scientific World Journal
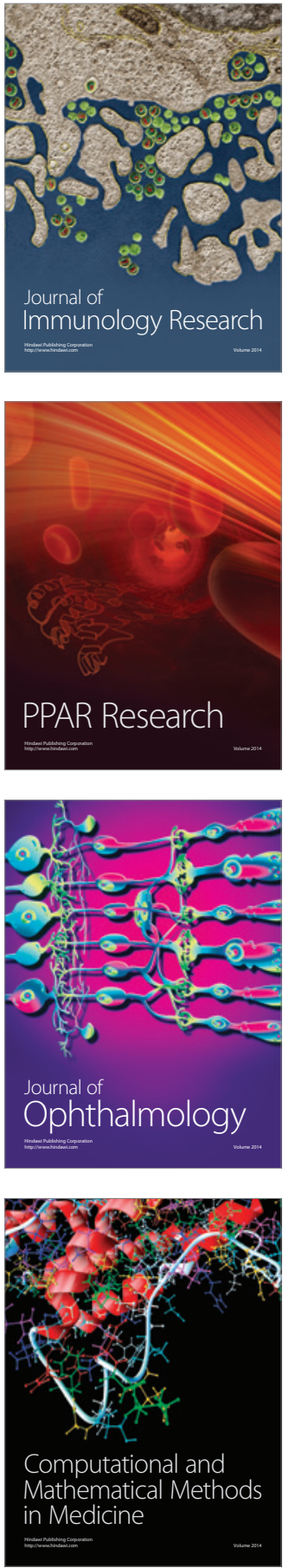

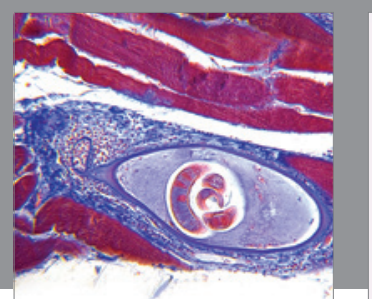

Gastroenterology Research and Practice

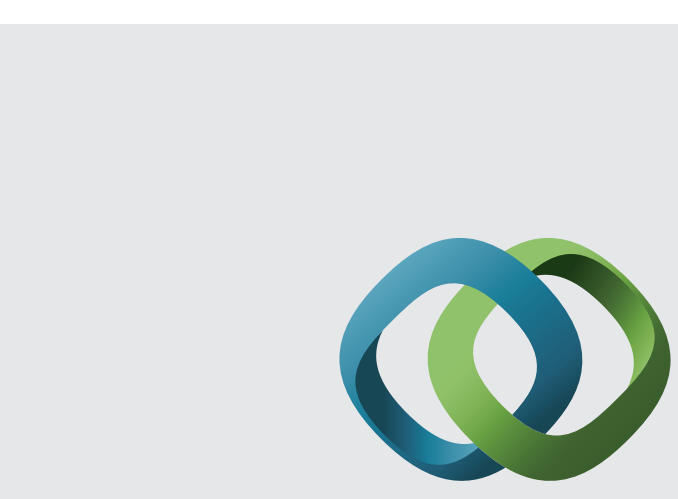

\section{Hindawi}

Submit your manuscripts at

http://www.hindawi.com
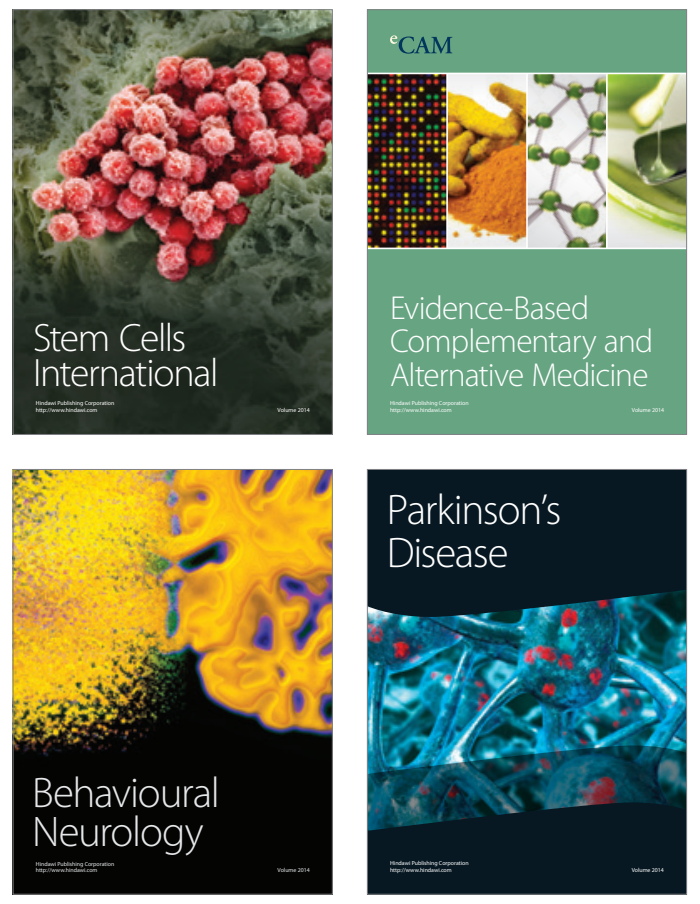
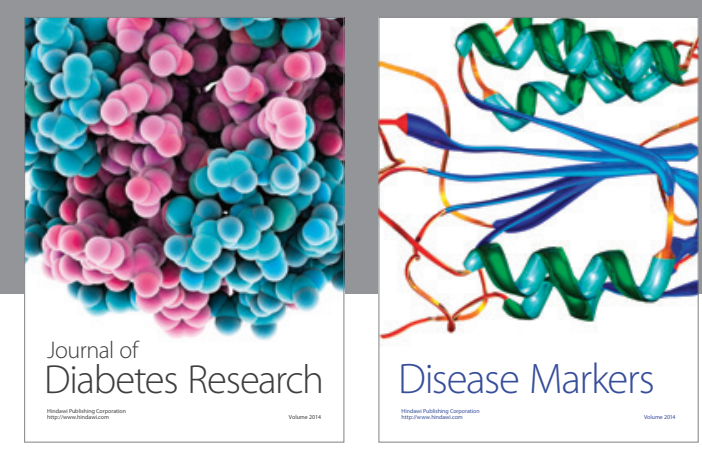

Disease Markers
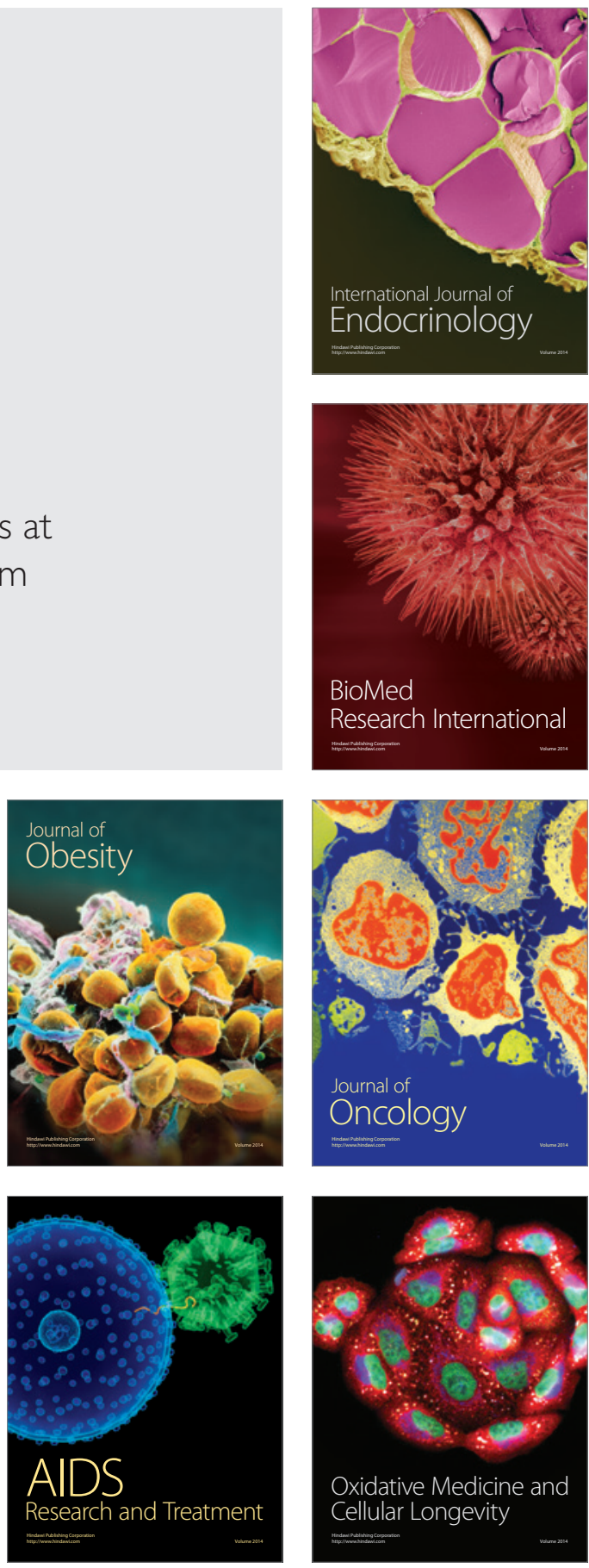